\title{
Research of Road Bridge Composite Steel Girder for Different Load Conditions
}

\author{
Amit Rajendra Malvi, Sharda P. Siddh, Udaysingh Patil
}

\begin{abstract}
A bridge structure is a mean by which a road, railway and many other services are carried over an obstacle such as a valley, river and other road or railway line, either with few number of supports at various locations or with no intermediate support. While finalization of any types of bridge; Economy, Strength, Safety are the basic key features that cannot be neglected in the construction of any bridge. However the Indian standards are basically derived from the British Standards only, but the basic concept behind that is same. Only the value of various parameters varies according to the design and fabrication/ erection practices which exist in India. In this paper a plate girder bridge is designed as per the Limit state method using the IS 800:2007, IRC: 24-2000, IRC: 6-2017 and analyzed with the help of STAAD.pro v8i software. Modeling and analysis of Deck Bridge was carried out by considering various live load conditions such as for Class A loading, 70R tracked and 70R wheeled vehicle. Design calculations are carried out for simply supported single span. Seismic and wind effects are not taken into account at the design stage. Based on the design and analysis results, conclusions are drawn to know the behavior of plate girder bridges for different load conditions. Results are presented in both graphically and tabular format.
\end{abstract}

Keywords: Steel bridges, Welded Plate Girder, Indian Road Congress, Class A Loading, 70R Loading.

\section{INTRODUCTION}

Bridges have been the most visible testimony to the contribution of engineers. The portion of the bridge structure above the foundation level and below the level of bearing is generally referred as the substructure and the portion above the level of bearing is referred as the superstructure as shown in figure 1. The design of substructure is as important part of the overall design for a bridge. Bridge substructure is a very crucial part of a bridge as it safely transfers the load from the superstructure to the earth in such a manner that the stresses generated in the soil are not excessive and the resulting deformations are also within the acceptable limits. Composite steel girder bridge is one of the most common types of medium span composite bridge constructed in India. Composite steel girder construction is used for single span and also for continuous multiple spans and it is particularly effective where the construction depth is limited. The girders

are braced together at supports position and at some

Revised Version Manuscript Received on August 19, 2019.

Er. Amit Rajendra Malvi,M. Tech (Structural Engineering), Department of Civil Engineering, ShriRamdeobaba College of Engineering and Management, Nagpur, Maharashtra, India.(email:amitmalvi678@gmail.com)

Dr. Sharda P. Siddh, Assistant Professor, Department of Civil Engineering, ShriRamdeobaba College of Engineering and Management, Nagpur, Maharashtra, India. (email: : shardasiddh.9@gmail.com)

Prof. Udaysingh Patil, Assistant Professor, Department of Civil Engineering, ShriRamdeobaba College of Engineering and Management, Nagpur, Maharashtra, India. (email:patil.udaysingh4@gmail.com) intermediate positions. The Composite action between the longitudinal girders and the reinforced concrete as shown in figure 2 is achieved by various means such as by using Shear Connectors etc as shown in figure 3. A plate girder is basically an 'I' section beam, and it is a deep flexural member. The plate girders are often used in structures having the span generally varying from 15 to $30 \mathrm{~m}$. By 1950's Plate girders were first assembled by bolting the flanges and web together with the help of angles. There could be multiple flange plates on top of each other when needed. When welding became popular then there was no more need for the angles anymore. Curtailment of the flange area is achieved in welded process by using narrower or thinner flange plates in regions of reduced bending moments, butt-welded to each other at the ends. The outer plates were made more successively narrower than the inner ones, to which they are connected with the help fillet welds along the longitudinal edges. Welded plate girders were replaced by the riveted and bolted plate girders in developed world due to their good quality, economy and aesthetics. Normally plate girders are provided with intermediate stiffeners in order to reduce the thickness of web plate and also to resist the buckling strength of the web. Plate girder provides more flexibility by changing the various dimensions of the component of plate girder, economy can also be achieved.

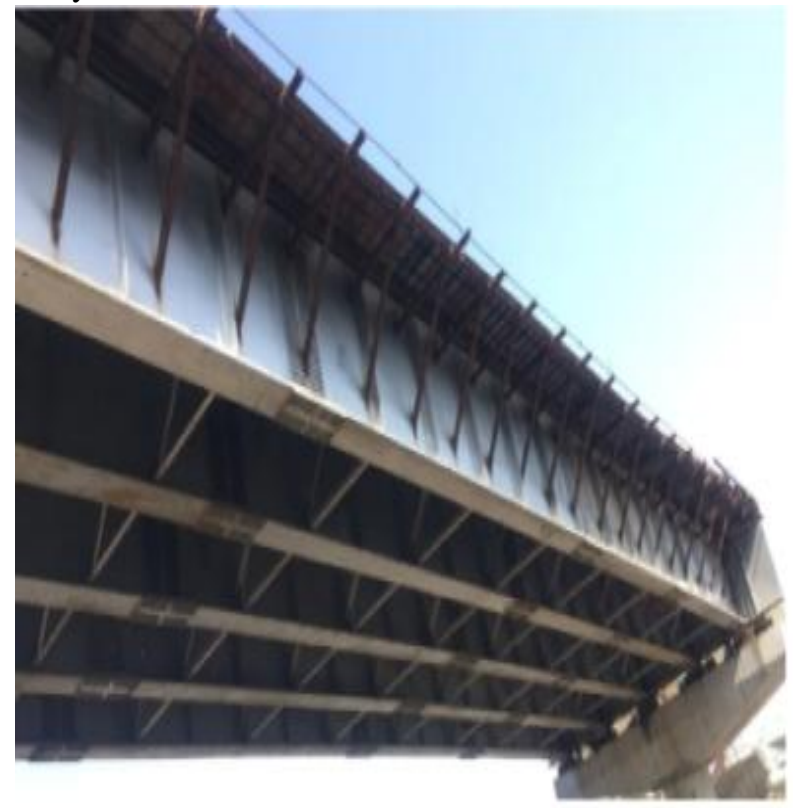

Fig 1. Steel Girder Bridge

Published By: Blue Eyes Intelligence Engineering \& Sciences Publication 


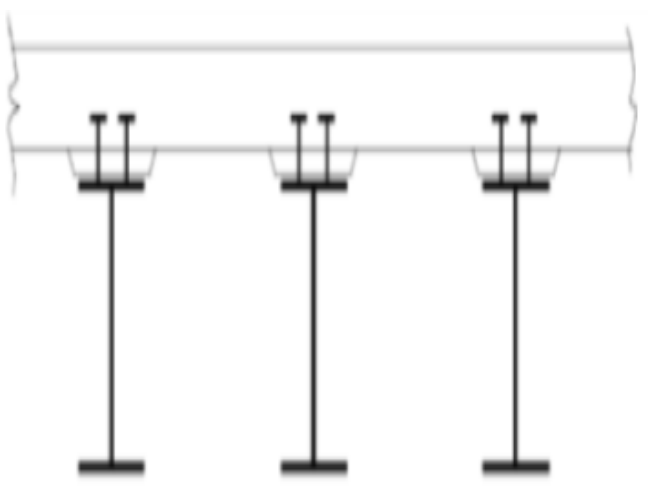

Fig 2. Composite section

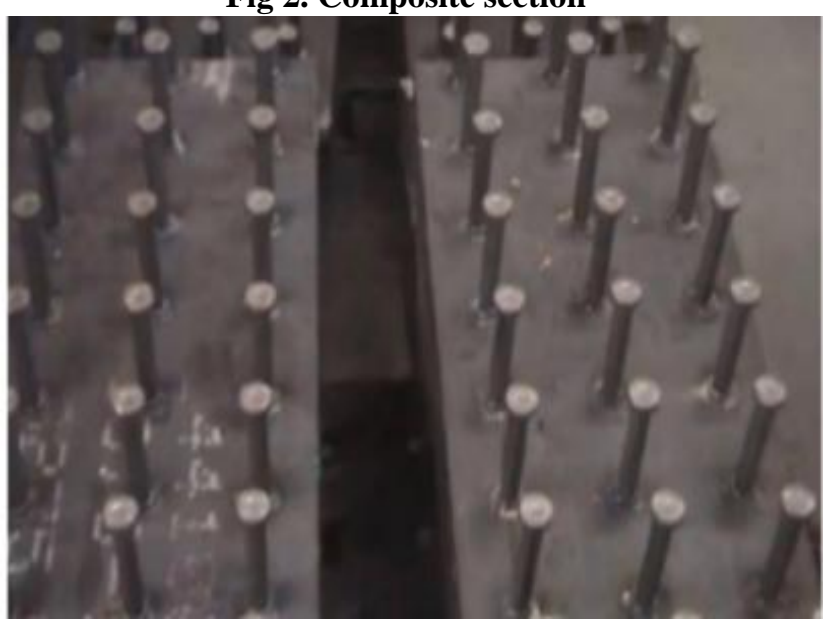

Figure 3. Shear Connector

The following information is provided on the basis of the various technical literatures available on this topic. Plate girder bridges are designed by trial and error approach due to the complexity of the design rules. The design of a composite girder is very tedious and time-consuming job for the designers. Mr. Shivraj D. Kopare, Prof. K. S. Upase, concludes that Plate Girder Bridge is the most economical bridge in terms of construction and the weight of the structure is also reduced. Experimental programmed was carried out by Amer F. Izzet, Aymen R. Mohammed, to investigate the flexural behavior of horizontally curved composite I-girder

decks subjected to standard bridge live loads and finally concludes that the deflection and the longitudinal girder strains increased with the increasing in curvature. PawanPatidar, Sunil Harne were the first to check the economic status of Plate Girder Bridge (Railway) on various spans keeping one parameter constant and other parameters varying. Ichiro sugimoto, Yoshinori yoshida, Akira tanikaga, proposed a method for the structural improvement of the existing railway steel bridge through installing concrete slab on existing steel girder. This method improves the load bearing capacity of the bridge ,extends their serviceable life ,

\begin{tabular}{|c|c|}
\hline Load & $\begin{array}{c}\text { Basic Load } \\
\text { Combination }\end{array}$ \\
\hline Dead load & 1.35 \\
\hline $\begin{array}{c}\text { SIDL excepting wearing } \\
\text { coat }\end{array}$ & 1.35 \\
\hline Wearing coat & 1.75 \\
\hline Live load & 1.5 \\
\hline Footpath live load & 1.5 \\
\hline
\end{tabular}

and reduces noise emission. Huiling Zhao, and Yong Yuan, presents the experimental studies of the flexural behavior of steel-concrete composite beams. Minh-Tung Tran, Vuong Nguyen Van Do, Tuan-Anh Nguyen, concludes that the bolts can be used successfully as the shear connectors for the SCC beam. The forms of the bolts as applied in specimens D1 (the bolt with the nut at the end) and D2 (the bolt bending at 90 deg. Hook) gave the great performances.

\section{LOADS, LOAD COMBINATIONS AND DESIGN PARAMETERS}

\section{Types of loads on Bridges:}

The following are the various types of loads that have to be considered for purpose of computing stresses wherever they are required.

- Dead load

- Live load

- Wind load

- Impact load

- Longitudinal forces

- Seismic load

- Forces on parapets

Combination of loads for limit state design:

Following load factors as per IRC: 6- 2014 is considered in the design:

(a) Partial safely factor for verification of strength (ULS) (Table 3.2 of IRC: 6-2014). Only basic load combinations are applicable for the design of superstructure.

(b) Partial safety factor for verification of serviceability limit state (SLS) (Table 3.3 of IRC: 6-2014)

\begin{tabular}{|l|l|l|l|}
\hline Load & $\begin{array}{l}\text { Rare } \\
\text { combinatio } \\
\mathrm{n}\end{array}$ & $\begin{array}{l}\text { Frequent } \\
\text { combinatio } \\
\mathrm{n}\end{array}$ & $\begin{array}{l}\text { Quasi- } \\
\text { Permanent } \\
\text { Combinatio } \\
\mathrm{n}\end{array}$ \\
\hline $\begin{array}{l}\text { Dead } \\
\text { load }\end{array}$ & 1.00 & 1.00 & 1.00 \\
\hline $\begin{array}{l}\text { SIDL } \\
\text { exceptin } \\
\text { g } \\
\text { wearing } \\
\text { coat }\end{array}$ & 1.00 & 1.00 & 1.00 \\
\hline $\begin{array}{l}\text { Wearing } \\
\text { coat }\end{array}$ & 1.20 & 1.20 & 1.20 \\
\hline $\begin{array}{l}\text { Live } \\
\text { load }\end{array}$ & 1.00 & 1.00 & 0.00 \\
\hline $\begin{array}{l}\text { Footpath } \\
\text { live load }\end{array}$ & 1.00 & 1.00 & 0.00 \\
\hline
\end{tabular}

Where, Rare combination is for checking stress limits; Frequent combination is for fatigue check using fatigue load and Quasi permanent combination is for checking cracks.

\section{Design parameters:}

For design of plate girder following parameters were considered accordingly:

1) IRC: $24-2010$

2) Span: $24.2 \mathrm{~m}$

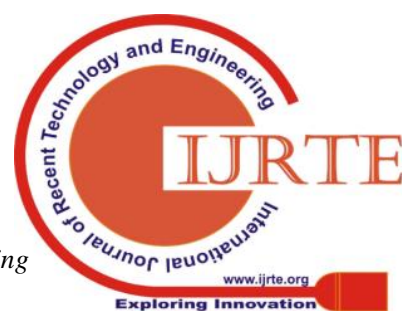


3) Boundary conditions: Simply Supported

4) Depth of web: Constant

5) Loading: IRC: 6-2017

6) Thickness of web: Constant

7) Design method: LSM

8) Flange area: Constant

9) Code: IS-800-2007

10) Flange thickness: Constant

\section{DESIGN EXAMPLE}

Design of two lane bridge girders:

Span $=24.2 \mathrm{~m}$

Deck Bridge:- Deck concrete $=\mathrm{M}-40$

Footpath width $=1.5 \mathrm{~m}$

Carriageway width $=7.5 \mathrm{~m}$

Crash barrier $=250 \mathrm{~mm}, 500 \mathrm{~mm}$

Total width $=12 \mathrm{~m}$

Spacing of main girder $=2.5 \mathrm{~m}$

Spacing of cross girder $=4.5 \mathrm{~m}, 5 \mathrm{~m}$

The RCC slab details are,

Main deck slab $=250 \mathrm{~mm}$ thick.

Wearing coat $=65 \mathrm{~mm}$ thick

Footpath $=150 \mathrm{~mm}$ thick.

\section{RESULT AND DISCUSSION}

This paper consist of designing of deck bridge as shown in figure $1 \& 2$ having five longitudinal girders and six cross girders as shown in figure $3 \& 4$. The deck bridge is checked for dead load model, live load combinations such as Class A loading, 70R Tracked vehicle, 70R Wheeled vehicle. For all the cases dimensions of the model was same. Deck Bridge was modelled in STAAD PRO software. Maximum bending moment and shear force for all the girders were computed in table format. Following cases are discussed below:

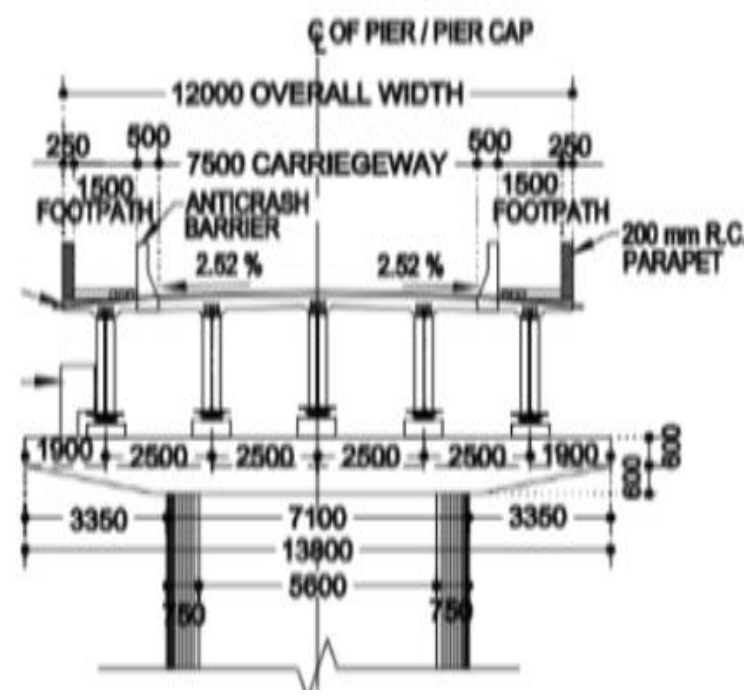

Fig 1. Cross section

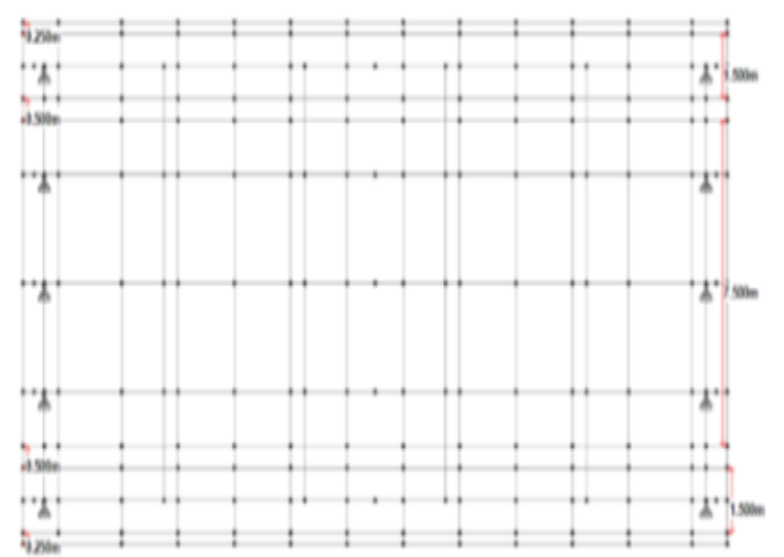

Fig 2. Bridge Deck

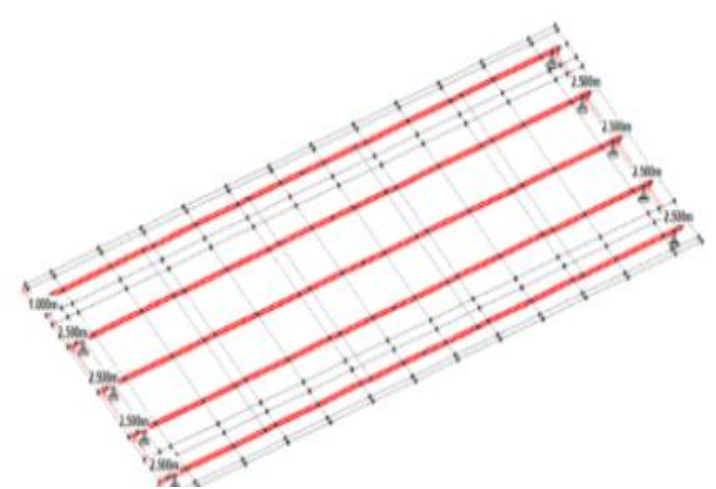

Fig 3. Longitudinal Girders

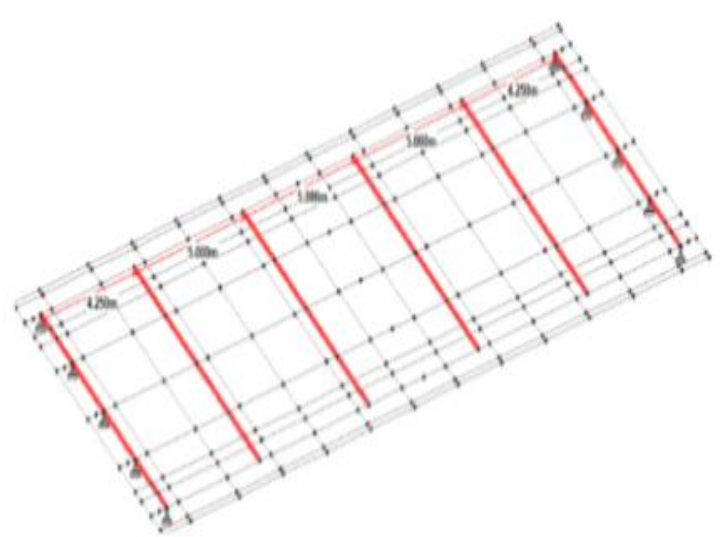

Fig 4. Cross Girders

A) FOR DEAD LOAD:-

Following figure 5, 6 shows the maximum bending moment and its bending moment diagram for girder 3 while the maximum shear force and shear force diagram for girder 3 are shown in figure 7,8 Similarly for all the girders maximum bending moment and shear force are calculated and computed in table form as shown in table 1. 


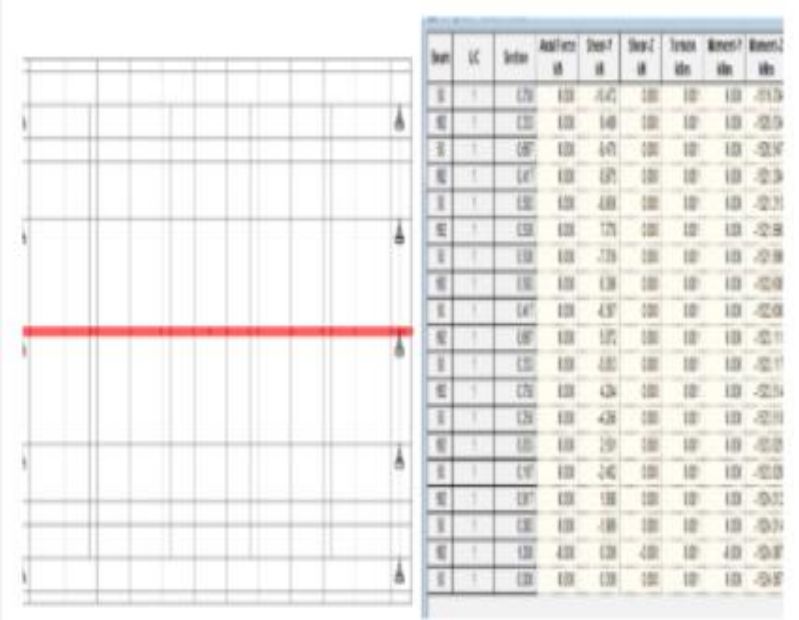

Fig 5. Maximum bending moment for G3

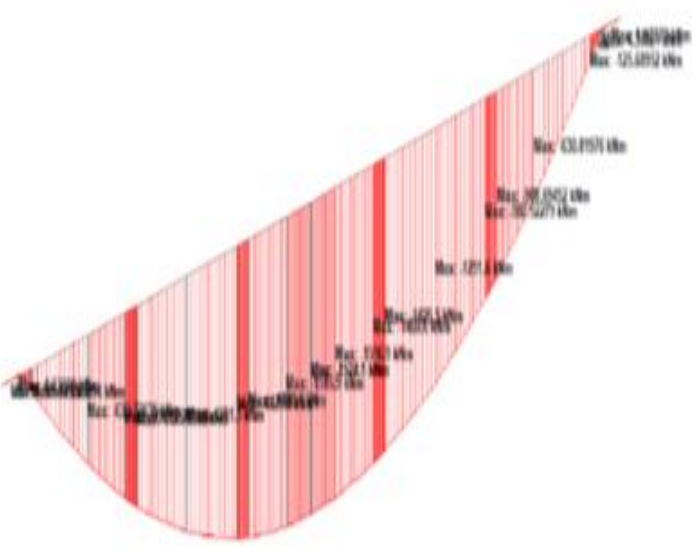

Fig 6. Dead load B.M.D for single girder

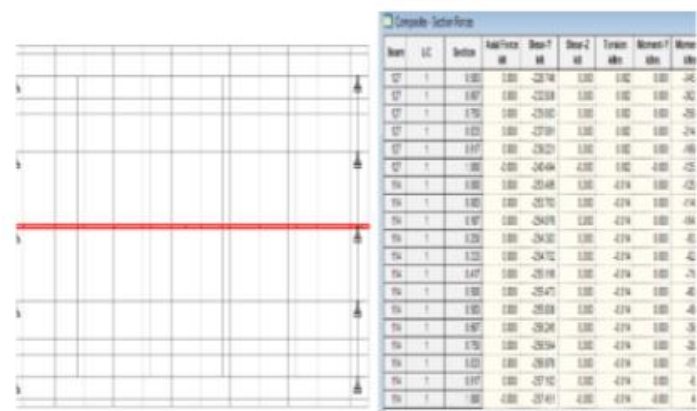

Fig 7. Max Shear Force for G3

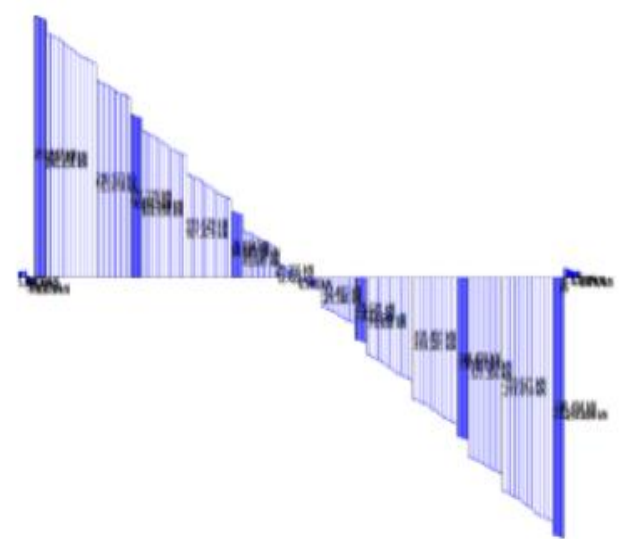

Fig 8. Dead load S.F.D for single girder
Table 1: Summery for B.M. \& S.F. (Dead Load, SIDL, SSDL, and Footpath Live Load)

\begin{tabular}{|c|c|c|c|c|c|c|c|c|}
\hline \multicolumn{7}{|c|}{ Maximum Bending Moment and Shear Force } \\
\hline \multicolumn{1}{|c|}{ S.N. } & $\begin{array}{c}\text { Dead Load (Slab, } \\
\text { Long Girder, Cross } \\
\text { Girder }\end{array}$ & \multicolumn{2}{|c|}{$\begin{array}{c}\text { SIDL (Crash } \\
\text { Barrier) }\end{array}$} & $\begin{array}{c}\text { SSDL (Wearing } \\
\text { Coat Paver } \\
\text { Blocks) }\end{array}$ & $\begin{array}{c}\text { Footpath Live } \\
\text { Load }\end{array}$ \\
\cline { 2 - 9 } & B.M. & S.F. & B.M. & S.F. & B.M. & S.F. & B.M. & S.F. \\
\cline { 2 - 9 } & KNm & KN & KNm & KN & KNm & KN & KNm & KN \\
\hline G1 & 1511.61 & 2.56 .87 & 487.70 & 106.42 & 309.11 & 57.03 & 196.65 & 43.72 \\
\hline G2 & 1520.74 & 255.09 & 426.66 & 65.31 & 297.87 & 47.57 & 166.42 & 23.01 \\
\hline G3 & 1524.07 & 257.45 & 401.32 & 52.83 & 294.01 & 47.34 & 155.45 & 19.60 \\
\hline G4 & 1520.59 & 256.94 & 426.68 & 64.08 & 297.88 & 47.33 & 166.42 & 22.71 \\
\hline G5 & 1511.26 & 255.89 & 487.72 & 104.44 & 309.11 & 56.31 & 196.65 & 42.88 \\
\hline
\end{tabular}

B) FOR 2 CLASS A LOADING:-

According to IRC $6: 2017$ if the carriageway width is between $5.3 \mathrm{~m}$ to $9.6 \mathrm{~m}$ then one lane of class $70 \mathrm{R}$ or two lanes for class $\mathrm{A}$ has to be designed. Following figure 9, 10 shows the Two Class A loading and moving load. While figure 11, 12 shows the maximum bending moment diagram and shear force and diagram for girder 1. Similarly for all the girders maximum bending moment and shear force are calculated and computed in table form as shown in table 2.

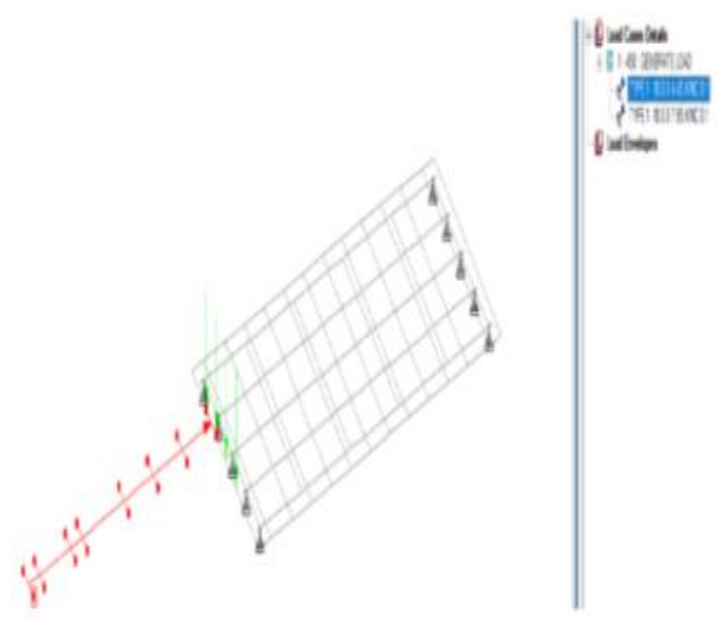

Fig 9. Class A loading

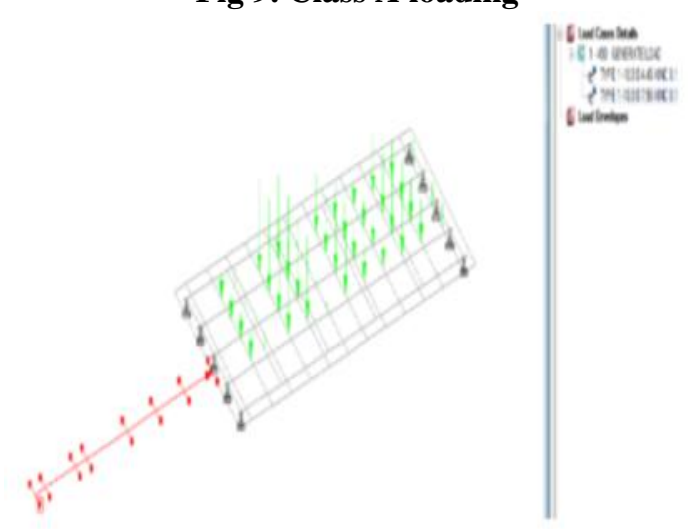

Fig 10. Class A moving load

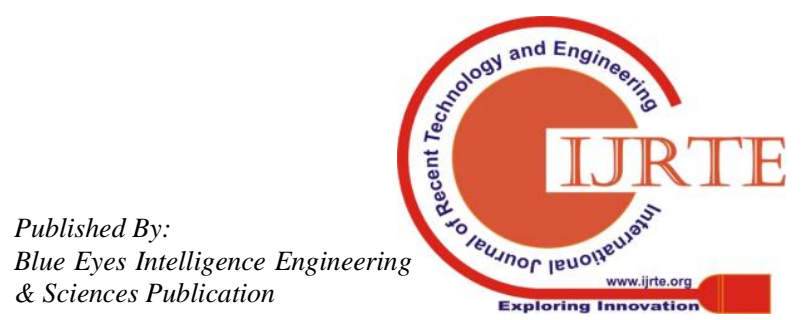




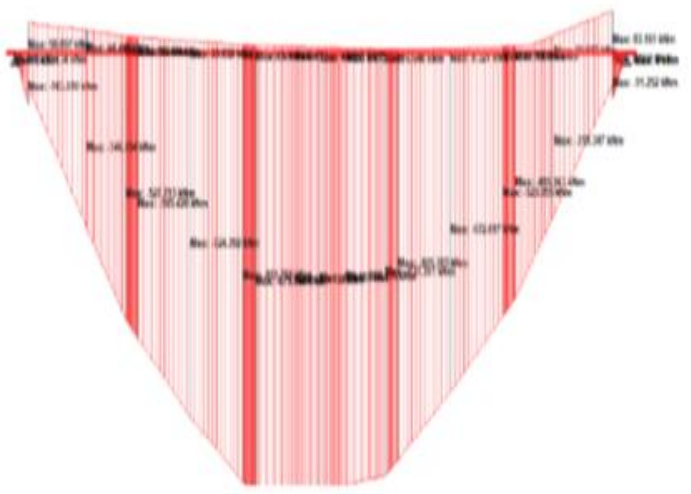

Fig 11. Bending Moment diagram for G1

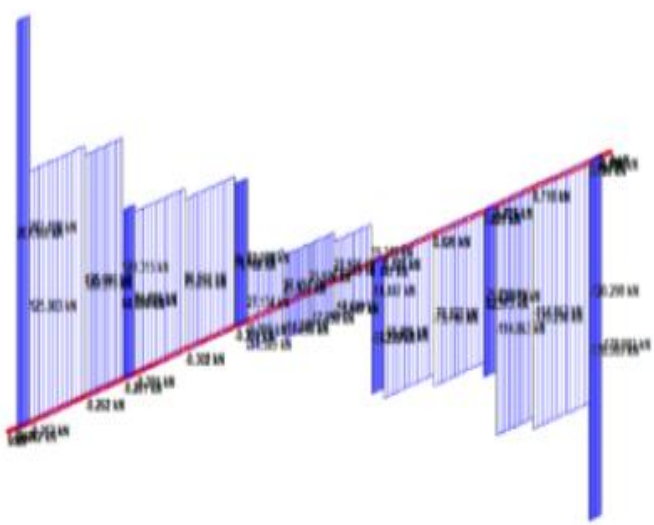

Fig 12. Shear Force diagram for G1

C) For 70R Tracked Vehicle:

Following figures 13, 14 shows 70R Tracked Vehicle model and moving load, while figure 15,16 shows maximum bending moment diagram and shear force diagram for girder 1. Similarly for all the girders maximum bending moment and shear force are calculated and computed in table form as shown in table 2.

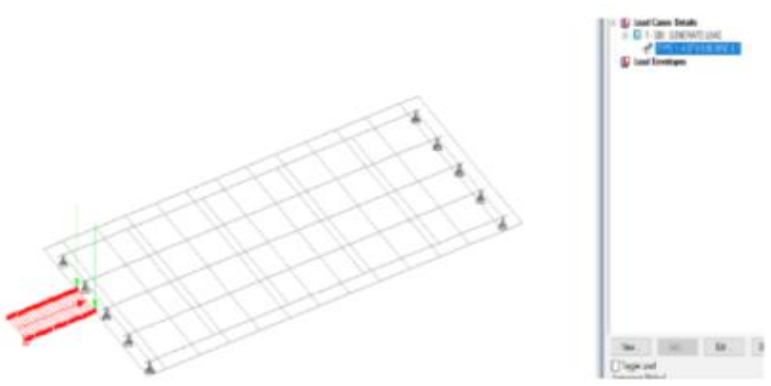

Fig 13. 70R Tracked Vehicle

Fig 14. 70 R Tracked Vehicle moving

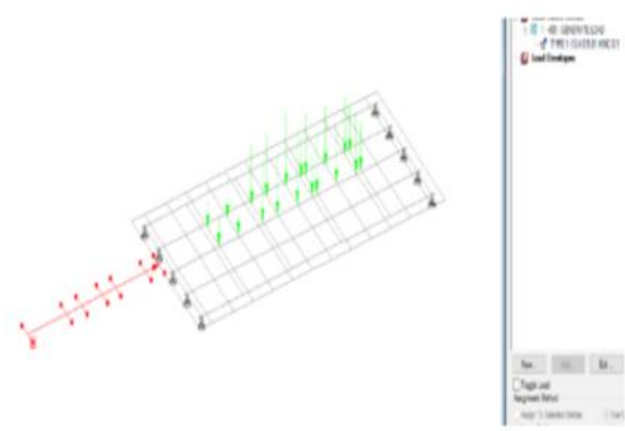

Fig 15. Bending Moment diagram for girder G1

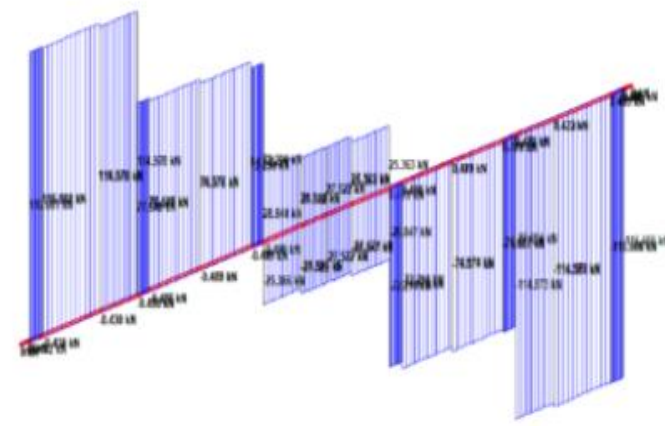

Fig 16: Shear Force diagram for girder G1

D) For 70R Wheeled Vehicle:

Following figures 17, 18 shows 70R Wheeled Vehicle model and moving load, while figure 19, 20 shows maximum bending moment diagram and shear force diagram for girder 1. Similarly for all the girders maximum bending moment and shear force are calculated and computed in table form as shown in table 2.

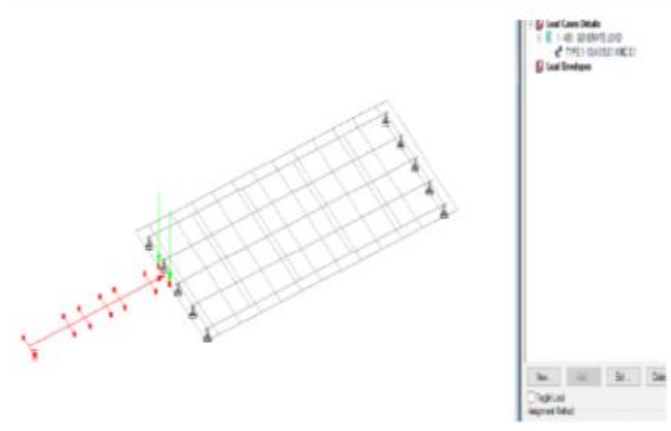

Fig 17: 70 R Wheeled Vehicle

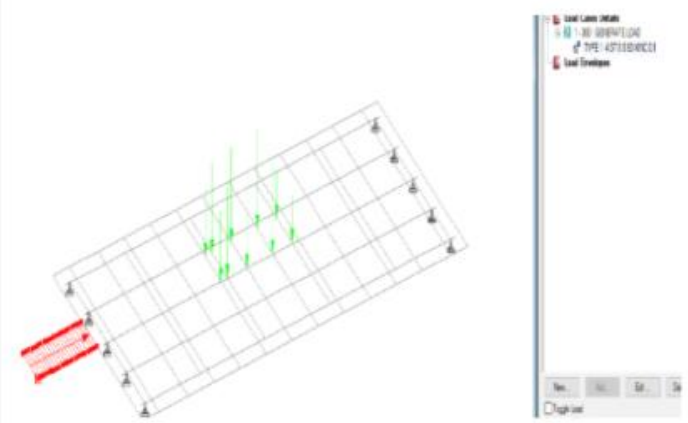

Fig 18: $70 \mathrm{R}$ Wheeled Vehicle moving load

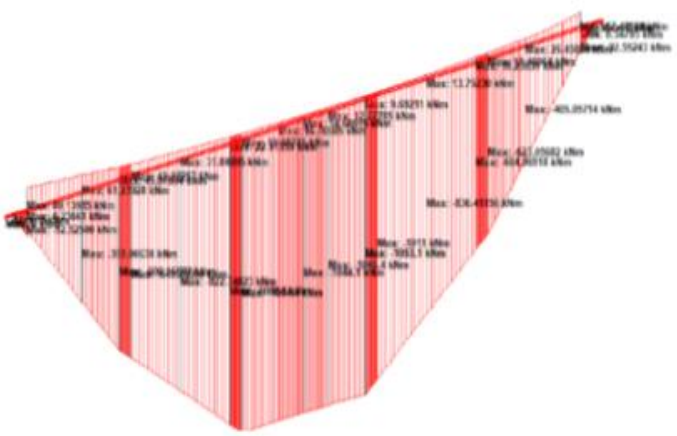

Fig 19 : Bending Moment diagram for G1

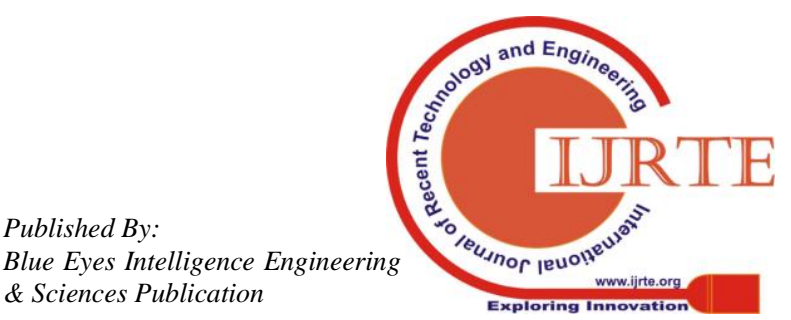




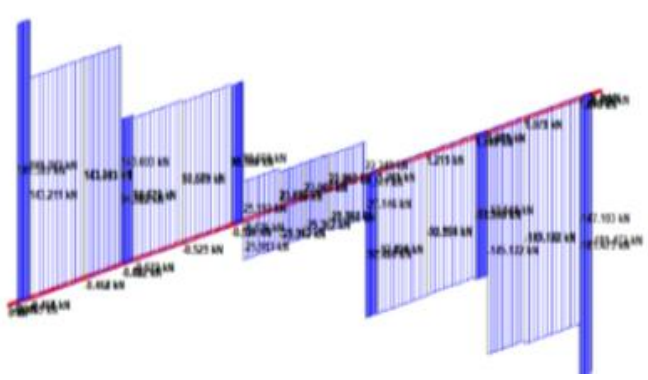

Fig 20: Shear Force diagram for G1

Table 2. Summary for B.M. \& S.F. for live Loads:(STAAD Results)

\begin{tabular}{|c|c|c|c|c|c|c|}
\hline \multicolumn{7}{|c|}{ Maximum Ben } \\
\hline \multicolumn{7}{|c|}{ LIVE LOAD } \\
\hline \multirow{3}{*}{ S.N } & \multicolumn{2}{|c|}{ 70R TRACK } & \multicolumn{2}{|c|}{$\begin{array}{l}70 \mathrm{R} \\
\text { WHEELED }\end{array}$} & \multicolumn{2}{|c|}{2 CLASS A } \\
\hline & B.M. & S.F. & B.M. & S.F. & B.M. & S.F. \\
\hline & $\mathrm{kNm}$ & $\mathrm{kN}$ & $\mathrm{kNm}$ & $\mathrm{kN}$ & $\mathrm{kNm}$ & $\mathrm{kN}$ \\
\hline G1 & 834.65 & $\begin{array}{l}116.6 \\
6\end{array}$ & $\begin{array}{l}1053.0 \\
7\end{array}$ & $\begin{array}{l}181.4 \\
7\end{array}$ & $\begin{array}{l}875.7 \\
1\end{array}$ & $\begin{array}{l}178.9 \\
0\end{array}$ \\
\hline $\mathrm{G} 2$ & $\begin{array}{l}1007.3 \\
2\end{array}$ & $\begin{array}{l}237.3 \\
3 \\
\end{array}$ & $\begin{array}{l}1112.8 \\
6\end{array}$ & $\begin{array}{l}263.6 \\
5\end{array}$ & $\begin{array}{l}925.6 \\
2\end{array}$ & $\begin{array}{l}169.5 \\
1\end{array}$ \\
\hline G3 & 942.24 & $\begin{array}{l}255.5 \\
9\end{array}$ & $\begin{array}{l}1001.8 \\
4\end{array}$ & $\begin{array}{l}266.7 \\
5 \\
\end{array}$ & $\begin{array}{l}876.8 \\
8 \\
\end{array}$ & $\begin{array}{l}175.7 \\
9\end{array}$ \\
\hline G4 & 605.15 & 95.56 & 703.38 & $\begin{array}{l}108.5 \\
1\end{array}$ & $\begin{array}{l}710.9 \\
4 \\
\end{array}$ & $\begin{array}{l}120.5 \\
5\end{array}$ \\
\hline G5 & 324.69 & 41.62 & 400.46 & 67.83 & $\begin{array}{l}509.4 \\
1\end{array}$ & $\begin{array}{l}104.2 \\
3\end{array}$ \\
\hline
\end{tabular}

\section{CONCLUSION}

It is concluded that the Steel is being used on highway and railway bridges successfully all over the world because of its high strength, resistance against fracture toughness, weld ability and a good resistance against weathering / corrosion action.

1. The STAAD analysis results indicate that the designed plate girder bridge is stable in bending moment, shear force, and deflection for various live load conditions such as for Class A loading, Class 70R tracked and wheeled vehicle.

2. 70R wheeled vehicle gives maximum value of Bending moment and Shear force as compared to 2 Class A loading and $70 \mathrm{R}$ Tracked vehicle.

\section{REFERENCES}

1. Minh-Tung Tran, Vuong Nguyen Van Do, Tuan-Anh Nguyen, "Behavior of steel-concrete composite beams using bolts as shear connectors", IOP Conf. Series: Earth and Environmental Science 143 (2018).

2. Huiling Zhao, and Yong Yuan, "Experimental studies on composite beams with high-strength steel and concrete", Steel and Composite Structures 10 (5), September 2010.

3. Shivraj D. Kopare, K. S. Upase, "Analysis of Plate Girder Bridge for Class-AA Loadings (Tracked Vehicles)", International Journal of Emerging Trends in Science and Technology, vol.2, issue 6, Pages 2645-2655, June.

4. JaroslavOdrobinak, Josef Vican, Jan Bujnak, "Verification of composite steel-concrete bridge behavior", Procedia Engineering, Volume 65, 2013, Pages 440-446.

5. Amer F. Izzet, Aymen R. Mohammed, "Experimental study on curved composite I-girder bridge subjected to live loading for Road Bridge", Journal of Engineering Science and Technology Vol. 13, No. 1 (2018) $226-241$.

6. VikashKhatri, Pramod Kumar Singh and P. R. Maiti, "Comparative study of prestressed steel - concrete composite bridge of different span length and girder spacing", International Journal of Modern Engineering Research Vol.2, Issue.5, Sep-Oct. 2012 pp-3917-3922.

7. IRC: 6-2017, "Standard specifications and Code of Practice for Road Bridges, Section II, Loads and Load combinations", Indian Road Congress, New Delhi.

8. IRC: 22-2008, "Standard Specifications And Code Of Practice For Road Bridges, Section VI, Composite Construction”, Indian Road Congress, New Delhi.

9. IRC24:2010, "Standard specifications and code of practice for Road Bridges, Section V, Steel Road Bridges”, Indian Road Congress, New Delhi.

10. IS800:2007, “General Construction in Steel - Code of Practice" Bureau of Indian Standards, New Delhi.

11. IS 456:2000, "Plain and Reinforced Concrete- code of practice, BIS, New Delhi.

12. IRC5:1998, "Standard Specifications and Code of Practice for Road Bridges" Section I.

13. Fundamentals of Structural steel design by ML Gambhir, McGraw Hill Education; First edition (1 July 2017).

14. IRC 112-2011, "Code of Practice for Concrete Road Bridges", Indian Road Congress, New Delhi. 